\title{
Pengelolaan Biaya Pendidikan yang Efektif pada Pelaksanaan Program Kegiatan PAUD Rinjani Sebagai Lembaga Trifungsi Pendidikan (TPA, KB dan TK)
}

\author{
Baiq Rohiyatun \\ Dosen FIP IKIP Mataram \\ Email: rbaiq@yahoo.co.id
}

\begin{abstract}
Abstrak: Pengelolaan biaya pendidikan yang transparan dan akuntanbel akan mendorong terjadinya pengelolaan biaya pendidikan yang efekif. Sedangkan pengelolaan yang efektif pada dasarnya melaksanakan manajemen yang meliputi proses: perencanaan (planning), pengorganisasian (organizing), pengarahan (directing), dan pengendalian (controlling) berbagai usaha anggota organisasi dan penggunaan sumber -sumber daya untuk mencapai tujuan organisasi yang telah ditetapkan. Tujuan penelitian adalah: Bagaimana pengelolaan biaya pendidikan lembaga trifungsi yang diselenggarakan oleh PAUD Rinjani. Penelitian ini menggunakan pendekatan kualitatif. Sedangkan jenis penelitian adalah studi kasus. Prosedur pengumpulan data dalam penelitian ini adalah: (1) Wawancara Mendalam (indept interview), (2) observasi Berperan serta, (3) studi dokumen. Tehnik analisis data adalah suatu proses sistematis pencarian dan penyesuaian transkip wawancara, catatan lapangan, dan materi lainnya yang telah terkumpul untuk meningkatkan pemahaman dan kemungkinan seseorang menyajikan apa-apa yang telah ditemukannya kepada orang lain. Temuan penelitian yaitu perencanaan yang dilakukan oleh PAUD Rinjani Unram dalam pengadaan biaya pendidikan melibatkan team pengelolaan PAUD Rinjani Unram. Dalam penelitian ini ditemukan berbagai bentuk bantuan dana PAUD yang diperoleh dari or angtua peserta didik, yaitu berupa iuran bulanan, sumbangan sukarela yang dapat berupa uang atau barang (bahan sembako seperti beras, kacang ijo, susu), bantuan tenaga, dan sebagai narasumber. Untuk mekanisme penetapan biaya pendidikan peserta didik melibatkan semua pemangku kepentingan internal antara lain: Pembina PAUD, pengelola, kepala sekolah dan guru sedangkan dalam penyusunan Rencana anggaran Pendapatan dan Belanja Sekolah (RAPBS) disesuaikan dengan pemasukan dan pengeluaran keuangan PAUD. Dalam menyusun RAPBS, prinsip penentuan program yang akan dimasukkan kedalam draf usulan RAPBS dilakukan berdasarkan tingkat urgensinya. Kepala PAUD Rinjani berpendapat bahwa program yang wajib diprioritaskan adalah program yang berkenaan dengan proses pembelajaran. Untuk tahap akhir yaitu evaluasi dalam rangka pertanggungjawaban penggunaan anggaran. Menurut Kepala sekolah untuk laporan RAPBS dilakukan setiap bulan untuk lembaga dan untuk dana bantuan yang ada seperti BOP satu kali dalam setahun. Sedangkan untuk laporan rutin bulanan disampaikan kepada Ketua Yayasan dan BPPU Universitas Mataram, sedangkan untuk laporan dana BOP kedinasan Pendidikan Kota Mataram. Adapun saran-saran dari hasil penelitian ini sebagai berikut: 1. Bagi Kepala Sekolah PAUD Rinjani Unram hendaknya memperhatikan kelengkapan dokumen penyusunan RAPBS, seperti struktur tim penyusun, notulensi rapat penyusunan RAPBS, dan rincian RAPBS yang jelas tentang sumber dana dan alokasi belanjanya, 2. Diharapkan mampu memperhatikan analisis lingkungan internal dan eksternal sekolah, dengan maksud agar penyusunan RAPBS sesuai dengan visi, misi, dan tujuan sekolah, 3 . Diperlukan sosialisasi dan koordinasi yang lebih intensif dari Kepala Sekolah kepada semua pemangku kepentingan yang terlibat dalam penyusunan RAPBS. Hal ini dalam rangka mempermudah untuk menyamakan persepsi antar pihak tentang penyusunan RAPBS.
\end{abstract}

Kata kunci: Pengelolaan Biaya Pendidikan, Lembaga Trifungsi Pendidikan

\section{Pendahuluan}

Dalam rangka mencerdaskan kehidupan bangsa, pemerintah selama ini telah berusaha mengembangkan banyak program pendidikan yang melibatkan Jurnal Ilmiah Mandala Education berbagai lembaga yang ada dalam masyarakat, program pendidikan tersebut guna menjangkau seluruh warga masyarakat dari yang atas sampai lapisan paling bawah. Pendidikan anak usia dini (PAUD) 173 
merupakan pendidikan yang amat mendasar dan strategi, karena masa usia dini merupakan masa emas dan peletak dasar (fondasi dasar) bagi pertumbuhan dan perkembangan anak selanjutnya. Lahirnya UU No. 20 tahun 2003 tentang Sistem pendidikan Nasional yang memuat pasal khusus tentang PAUD merupakan bukti adanya komitmen nasional terhadap PAUD.

Dalam pengembangan program PAUD di masyarakat dewasa ini partsispasi aktif seluruh warga masyarakat dipandang sangat penting artinya bagi kelancaran pelaksanaan kegiatan dan tercapainya tujuan secara mantap. Oleh karena itu partisipasi masyarakat selalu diusahakan untuk dikembangkannya sejak awal pelaksanaan program, dan diharapkan bisa berlangsung terus sampai tercapainya tujuan program.

Dalam rangka mengembangkan peran serta masyarakat khususnya program PAUD, para tokoh masyarakat baik formal maupun non formal sangat penting peranannya, terutama dalam mempengaruhi, memberi contoh dan menggerakkan keterlibatan seluruh warga masyarakat lingkungan guna mendukung keberhasilan program. Sebagian besar pelaksana PAUD (Pendidikan Anak Usia Dini) adalah organisasi kemasyarakatan, lembaga swadaya masyarakat, maupun LSM, dan hanya sebagian yang ditangani oleh pemerintah, pemerintah lebih berperan sebagai fasilitator terhadap pelaksanaan PAUD yang ada selama ini. Lemahnya sosialisasi tentang penyelenggaraan PAUD selama ini berdampak negatif terhadap pelaksanaan program PAUD.

Peran serta masyarakat secara luas memberikan andil yang besar terutama dalam mendukung sarana dan prasarana serta sumberdaya manusianya. Peran dan partisipasi masyarakat menjadi hal yang sangat mendasar, namun banyak kita jumpai ketimpangan yang ada dalam pelaksanaan PAUD. Ada yang sangat berhasil dilihat dari banyak dan lengkapnya fasilitas yang dimiliki di pelaksanaan PAUD serta sumber daya manusia yang berkualitas sebagai pengelola dan sebagai Tutor. Di lain pihak banyak Jurnal Ilmiah Mandala Education pula pengelengaraan PAUD yang tak mampu melaksanakan program kegiatannya, bahkan sekedar memenuhi standar minimal yang dipersyarakatkan.

Kemampuan implementasi manajemen suatu program merupakan landasan utama bagi kelancaran pelaksanaana program, makna positif atau negatif sebagai hasil implementasi manajemen terhadap program akan menjadi pendorong atau penghambat bagi pelaksanaan suatu program. Inti sari dari manajemen adalah untuk mengakui adanya kenyataan kelangkaan dan lalu memahami bagaimana caranya mengorganisir masyarakat dengan cara yang menghasilkan penggunaan sumber dapat paling efisien. Manajemen dan partisipasi masyarakat memiliki dampak terhadap kualitas penyelengaraan program pendidikan anak usia dini, bila manajemen dan partisipasi masyarakat positif, akan memiliki dampak yang positif pula terhadap pelaksanaan program PAUD, baik dalam bentuk kelompok bermain maupun penitipan anak, sebaliknya jika manajemen pengelolaan pendidikan anak usia dini serta partisipasi masyarakat negatif, berpengaruh pula terhadap lemahnya penyelenggaraan pendidikan anak usia dini.

PAUD sebagai pendidikan yang diselenggarakan sebelum jenjang pendidikan dasar, memiliki kelompok sasaran anak usia 0-6 tahun yang sering disebut sebagai masa emas perkembangan (Direktorat PAUD, 2006), yang populer dikenal sebagai Golden Age. Anak-anak pada usia dini rentan terhadap segala tekanan dan paksaan serta hal-hal yang dapat memicu stress. Penanganan dan pemberian stimulus pada anak yang tidak tepat dapat merugikan perkembangan anak itu sendiri. Oleh karena itu penyelenggaraan dan pengelola PAUD hendaknya memperhatikan dan menyesuaikan pembelajaran sesuai dengan tahap- tahap perkembangan anak. Sebagian besar pelaksana lembaga PAUD adalah organisasi kemasyarakatan, lembaga swadaya masyarakat, maupun LSM, dan hanya sebagian yang ditangani oleh pemerintah, pemerintah lebih berperan sebagai fasilitator terhadap pelaksanaan PAUD yang ada selama ini. 
Dalam pelaksanaannya yang terjadi di lembaga yang menyelenggarakan PAUD lebih fokus pada satu jenis pelayanan misalnya Kelompok Bermain saja, masih kurang lembaga penyelenggara PAUD yang melaksanakan TRIFUNGSI kegiatan seperti (Penitipan anak, Kelompok Bermain dan Taman Kanak-kanak) khususnya di Kota Mataram Nusa Tenggara Barat. Kegiatan PAUD yang melaksanakan trifungsi kegiatan ini berdampak besar terhadap pengelolaan pembiayaan program pendidikan yang dilaksanakan sehingga bisa menghasilkan peserta didik yang berkualitas. Berdasarkan studi pendahuluan yang peneliti lakukan di PAUD Rinjani Mataram bahwa lembaga tersebut melaksanakan tiga fungsi pendidikan yaitu Tempat Penitipan Anak (TPA), Kelompok Bermain (KB) dan Taman Kanak-Kanak. Tentunya ketiga fungsi tersebut memiliki kebutuhan dan pengelolaan program pendidikan yang berbeda.

\section{Pengelolaan anggaran biaya}

merupakan kegiatan yang dilaksanakan pada setiap penyelengaraan program kegiatan termasuk penyelengaraan Pendidikan Anak Usia Dini (PAUD). Pengelolaan biaya pendidikan dalam implementasinya perlu diperhatikan kesesuaian antara perencanaan, dan pelaksanaan yang keduanya memiliki peran yang strategis dalam rangka tercapainya tujuan yang telah ditetapkan. Perencanaan memerlukan beberapa pertimbangan antara lain : dari mana sumber biaya diperoleh, untuk kegiatan apa saja biaya digunakan, siapa yang dilibatkan dalam perencanaan dan kapan perencanaan dibuat, sedangkan pelaksanaan merupakan penjabaran operasional dalam bentuk kegiatan pendidikan sebagai implementasi dari perencanaan. Disisi lain kemampuan pengelola dalam melaksanakan manajemen di program PAUD juga mempengaruhi terjadinya partisipasi masyarakat.

Pengelolaan biaya pendidikan yang transparan dan akuntanbel akan mendorong terjadinya pengelolaan biaya pendidikan yang efekif. Sedangkan pengelolaan yang efektif pada dasarnya melaksanakan manajemen yang meliputi proses : perencanaan (planning), pengorganisasian (organizing), pengarahan (directing), dan pengendalian Jurnal Ilmiah Mandala Education (controlling) berbagai usaha anggota organisasi dan penggunaan sumber -sumber daya untuk mencapai tujuan organisasi yang telah ditetapkan. Sebagai lembaga berstatus swasta menanggung biaya pendidikan secara mandiri sesuai dengan Peraturan Pemerintah Nomor 27 Tahun 1990 tentang pendidikan prasekolah, Bab IX pasal 15 menegaskan bahwa: "Penyelenggara taman kanak-kanak bertanggung jawab atas biaya pendidikan yang diperlukan dan dapat diperoleh dari sumbangan orangtua/wali yang bersangkutan yang besarnya tidak boleh melebihi kemampuanya.

Adapun tujuan dari penelitian ini adalah untuk menemukan jawaban terhadap permasalahan yang dirumuskan pada Latar Belakang penelitian. Dengan demikian tujuan penelitian adalah: Bagaimana pengelolaan biaya pendidikan lembaga trifungsi yang diselenggarakan oleh PAUD Rinjani.

\section{Kajian Pustaka}

Pengelolaan anggaran biaya merupakan kegiatan yang dilaksanakan pada setiap penyelengaraan program kegiatan termasuk penyelengaraan Pendidikan Anak Usia Dini (PAUD). Pengelolaan biaya pendidikan dalam implementasinya perlu diperhatikan kesesuaian antara perencanaan, dan pelaksanaan yang keduanya memiliki peran yang strategis dalam rangka tercapainya tujuan yang telah ditetapkan. Perencanaan memerlukan beberapa pertimbangan antara lain : dari mana sumber biaya diperoleh, untuk kegiatan apa saja biaya digunakan, siapa yang dilibatkan dalam perencanaan dan kapan perencanaan dibuat, sedangkan pelaksanaan merupakan penjabaran operasional dalam bentuk kegiatan pendidikan sebagai implementasi dari perencanaan.

Setiap kegiatan perlu diatur agar kegiatan berjalan dengan tertib, lancar, efektif dan efisien (Depdiknas 2007: 6). Keuangan sekolah merupakan bagian yang sangat penting karena setiap kegiatan sekolah membutuhkan uang. Untuk itu, kegiatan pengelolaan keuangan sekolah perlu dilakukan dengan baik. Mulyono (2010 : ) mengemukakan bahwa keberhasilan sekolah dalam menyelenggarakan pendidikan yang 
berkualitas juga tidak terlepas dari perencanaan anggaran pendidikan yang mantap serta pengalokasian dana pendidikan yang tepat sasaran dan efektif. Pembiayaan pendidikan tidak hanya menyangkut analisis sumber- sumber pendapat pendidikan saja, namun lebih pada penggunaan dana secara efektif dan efisien. Semakin efisien dana yang digunakan dalam proses pendidikan, maka berkurang pula dana yang diperlukan untuk mencapai tujuan- tujuannya. Dengan pencapain efisiensi dana pendidikan, maka tercapai pula efektifitas kegiatan dalam pencapaian tujuan pendidikan.

Permasalahan pertama yang kita hadapi di lapangan dalam usaha melaksanakan program Pendidikan anak Usia Dini adalah belum meratanya tingkat partisipasi masyarakat belajar partisipasi masyarakat adalah sebagai dukungan rakyat. Dalam hal program kegiatan Pendidikan Anak Usia Dini pada masyarakat tiap desa akan mempengaruhi seberapa besar kamauan rakyat menanggung biaya penyelengaraan PAUD. Disisi lain kemampuan pengelola dalam melaksanakan manajemen di program PAUD juga mempengaruhi terjadinya partisipasi masyarakat. Pengelolaan biaya pendidikan yang transparan dan akuntanbel akan mendorong terjadinya pengelolaan biaya pendidikan yang efekif. Sedangkan pengelolaan yang efektif pada dasarnya melaksanakan manajemen yang meliputi proses : perencanaan dan pengorganisasian sumber daya untuk mencapai tujuan organisasi yang telah ditetapkan (Sriyanto, 2009)

Proses pengelolaan keuangan di PAUD meliputi: (1) Perencanaan Angaran, (2) Strategi mencari sumber dana PAUD, (3) penggunaan keuangan PAUD, pengawasan dan evaluasi anggaran dan (5) Pertanggung jawaban. Selanjutnya, pemasukan dan pengeluaran keuangan PAUD diatur dalam Rancangan Anggaran pendapatan dan Belanja (RAB). Kegiatan di atas di jabarkan sebagai berikut :
1. Penyusunan Rencana
Pendapatan dan Belanja (RAPB)
Rencana Anggaran Pendapatan dan Belanja (RAPB) harus berdasarkan pada rencana pengembangan lembaga dan Jurnal Ilmiah Mandala Education

merupakan bagian dari rencana operasional tahunan. Penyusunan RAPB tersebut harus melibatkan pengelola, pendidik dan forum orang tua. RAPB perlu disusun pada setiap tahun ajaran dengan memastikan bahwa alokasi anggaran bisa memenuhi kebutuhan sekolah secara optimal.

1.1 Prinsip penyusunan RAPB, antara lain:

a. RAPB harus benar-benar difokuskan pada peningkatan pembelajaran murid secara jujur, bertanggung jawab dan transparan

b. RAPB harus ditulis dalam bahasa sederhana dan jelas dan dipajang ditempat terbuka di sekolah

c. Dalam menyusun RAPB, sekolah sebaiknya secara seksama memprioritaskan pembelanjaan dana sejalan dengan rencana pengembangan sekolah

1.2 Proses Penyusunan RAPB meliputi:

a. Menggunakan tujuan jangka jangka menengah dan jangka pendek yang ditetapkan di dalam rencana pengembangan sekolah

b. Menghimpun, merangkum dan mengelompokkan isu-isu dan masalah utama kedalam berbagai bidang yang luas cakupannya

c. menyelesaikan analisis kebutuhan

d. Memprioritaskan kebutuhan

e. Mengkonsultasikan rencana aksi yang ditunjukkan/dipaparkan dalam rencana pengembangan sekolah

f. mengidentifikasi dan memperhitungkan seluruh sumber pemasukan

g. Menggambarkan rincian (waktu, biaya, orang yang bertanggung jawab, pelaporan dan sebagainya),dan mengawasi serta memantau kegiatan dari tahap perencanaan menuju tahap penerapan hingga evaluasi.

\section{Pertanggungjawaban dan pengawasan Keuangan Sekolah}

Lembaga PAUD wajib menyampaikan laporan dan evaluasi di bidang keuangan terutama mengenai penerimaan dan pengeluaran keuangan lembaga yang harus dilakukan setiap semester. Dana yang digunakan akan dipertanggungjawabkan 176 
setiap semester yang akan dijadikan laporan kepada pihak-pihak yang terlibat dan pengelolaan lembaga atau kepada sumber dana. Pertanggungjawaban ini bertujuan untuk mengetahui semua pengelolaan anggaran yang telah direncanakan apakah sesuai dengan tujuan atau peruntukannya.

Menurut Bafadal (2005) ada beberapa kegiatan yang dapat dilakukan dalam melakukan pengawasan keuangan di taman kanak-kanak, baik pengawasan fungsional maupun pengawasan melekat. Kegiatankegiatan yang dimaksud adalah sebagai berikut: (1) pengawas mempelajari rencana anggaran yang telah disusun oleh taman kanak-kanak, dan (2) pengawas mempelajari semua catatan yang ada di dalam buku kas serta bukti-bukti sahnya (kwitansi maupun faktur). Hal-hal yang dipertanyakan dalam mempelajari buku kas dan bukti-buktinya meliputi hal-hal sebagai berikut:

1. Apakah semua pemasukan keuangan telah sesuai dengan rencana anggaran?

2.Apakah semua pengeluaran keuangan telah sesuai dengan rencana anggaran?

3. Apakah semua bukti (kwitansi dan faktur) pemasukan dan pengeluaran keuangan yang ada sah?

4. Apakah semua catatan pemasukan dan pengeluaran yang tertulis di dalam buku kas sesuai dengan bukti-bukti pengeluaran yang ada.

\section{Matode Penelitian}

Penelitian ini dilaksanakan di PAUD Rinjani Jl. Pendidikan No. 37 Kota Mataram. Provinsi Nusa Tenggara Barat. Penelitian ini menggunakan pendekatan kualitatif. Menurut Moleong (2001) penelitian dengan pendekatan kualitatif mengandung karakteristik yaitu: berakar pada latar alamiah sebagai kebutuhan, mengandalkan manusia sebagai alat peneliti, memanfaatkan metode kualitatif, mengadakan analisis data secara induktif, bersifat deskriptif, lebih mementingkan proses daripada hasil, membatasi studi dengan fokus, memiliki seperangkat kriteria untuk memeriksa keabsahan data, rancangan penelitian bersifat sementara dan hasil penelitiannya disepakati oleh kedua belah pihak (peneliti dan yang diteliti).

Penelitian kualitatif adalah penelitian Jurnal Ilmiah Mandala Education dengan paradigma naturalistik. Menurut Muhajir (dalam Umar, 2005) menuntut dilaksanakannya penelitian dalam konteks natural, dengan harapan makna yang diangkat dari penelitian tersebut memang dari konteksnya bukan dari prakonsep penelitiannya; pemaknaan hasil interview dan atau observasi tidak dapat dikaitkan dalam waktu dan konteks tertentu. Sedangkan jenis penelitian adalah studi kasus, yaitu "melakukan penelitian pada fokus atau subyek tertentu.yang memang memiliki keunikan tertentu yang berbeda dengan fokus atau subyek yang lain pada umumnya" (Riyanto, 2007). Bogdan dan Biklen (dalam Riyanto, 2007) juga mengatakan, studi kasus ialah mengkaji secara rinci atas satu latar, atau satu orang subyek atau suatu tempat penyimpanan dokumen, atau satu peristiwa tertentu. Dalam penelitian kasus akan dilakukan penggalian data secara mendalam dan menganalisis secara intensif interaksai faktor-faktor yang terlibat di dalamnya.

Prosedur pengumpulan data dalam penelitian ini adalah: (1) Wawancara Mendalam (indept interview), (2) observasi Berperan serta, (3) studi dokumen. Menurut Marshall (1989), ketiga teknik tersebut yang selalu digunakan dalam penelitian Kualitatif.

Keabsahan data merupakan hal yang amat penting dalam penelitian, karena akan menjamin keterpercayaan data tersebut dalam pemecahan masalah yang diteliti. Dalam penelitian kualitatif, peneliti merupakan instrument utamanya. Oleh karena itu uji validitas dan reabilitas instrument dilakukan dengan cara pengecekan dan pengauditan datanya (Lincoln dan Guba, 1985).

1. Uji kredibilitas

Tujuan dilakukan uji kredibilitas sebagaimana dikemukakan oleh Nasution (1996) adalah untuk membuktikan sejauh mana suatu data penelitian yang diperoleh mengandung kebenaran sehingga dapat dipercaya.

Cara yang dilakukan untuk menjaga kredibilitas aktivitas validasi antara lain dengan: Triangulasi, Membercheck dan Pendapat para ahli (Expert Judgment) 


\section{Dependabilitas}

Peneliti adalah instrument utama (key instrument) maka agar penelitian ini dapat dipercaya (devendability and validity) dan dapat dipertanggungjawabkan secara ilmiah, maka dalam penelitian ini peneliti melakukan uji keakuratan perolehan penelitian dan peninjauan konsep untuk mendapatkan pertimbangan-pertimbangan khusus terhadap hasil penelitian ini.

3. Konfirmabilitas

Konfirmabilitas adalah tehnik yang digunakan untuk menilai obyektifitas dan kualitas dari hasil temuan penelitian, untuk itu diperlukan persetujuan pandangan dari beberapa pandangan, pendapat dan penemuan seseorang termasuk kedua orang dosen pembimbing sebagai dependability audit. Untuk mendapat kepastian data yang diperoleh selama pengumpulan data maka peneliti melakukan konfirmasi dengan para informan di dua perguruan tinggi. Jika sudah disepakati oleh beberapa orang maka hasil penelitian dianggap sudah obyektif, namun penekanannya tetap mengacu pada temuan data dilapangan. Analisis data adalah suatu proses sistematis pencarian dan penyesuaian transkip wawancara, catatan lapangan, dan materi lainnya yang telah terkumpul untuk meningkatkan pemahaman dan kemungkinan seseorang menyajikan apaapa yang telah ditemukannya kepada orang lain (Bogdan \& Biklen 1998).

\section{Hasil dan Pembahasan}

\section{Profil Sekolah (TPA, KB, TK)}

Visi (Beriman, Bertaqwa, Berbudaya, Kreatif, Mandiri dan Berwawasan luas), Misi (1). Meningkatkan keimanan dan ketaqwaan terhadap Alloh SWT/ Tuhan yang Maha Esa, (2). Melaksanakan kegiatan yang bernuansa religius, (3). Menciptakan lingkungan sekolah yang aman, nyaman, rapi, bersih dan menyenangkan, (4). Menumbuhkan kedisiplinan peserta didik dan warga sekolah, (5). Mengembangkan kreativitas peserta didik agar menjadi terampil dan mandiri, (6). Mengembangkan kemampuan peserta didik melalui pengenalan ilmu Pengetahuan, Teknologi dan Seni, (7). Menumbuhkan sikap kecintaan terhadap budaya daerah.
Tujuan TPA RINJANI UNRAM: (1). Memiliki rasa keimanan dan ketaqwaan terhadap Alloh SWT/ Tuhan yan Maha Esa, (2). Terbiasa hidup rukun, damai, harmonis dan toleransi, (3). Terciptanya lingkungan sekolah yang aman, nyaman, rapi dan bersih, (4). Memiliki sikap kedisiplinan yang tinggi, (5), Memiliki kreativitas yang tinggi melalui pengembangan bakat dan minat peserta didik, (6). Memiliki wawasan yang luas melalui pengembangan Ilmu Pengetahuan Teknologi dan Seni sehinggga siap memasuki pendidikan lebih lanjut, (7). Memiliki rasa kecintaan terhadap budaya daerah.

LOKASI: Lokasi TPA Rinjani terletak di tengah-tengah lingkungan kampus Universitas Mataram, jalan Pendidikan no 37 Mataram NTB. No telpon (0370) 625063.

SARANA

PRASARANA:Status

Bangunan : (1). Surat Kepemilikan Tanah : Milik Unram, (2). Luas Tanah : $1000 \mathrm{~m}^{2}$, luas Bangunan : $750 \mathrm{~m}^{2}$, 5 sentra beserta perlengkapannya yaitu: 1 sentra balok, 1 sentra seni, 1 sentra persiapan, 1 sentra bermain peran, 1 sentra bahan alam, 1 sentra Imtaq Permainan Outdoor terdiri dari: 2 jungkat jungkit, 4 buah ayunan, 1 set perosotan, 4 tangga majemuk, 1 berugaq permanen ukuran $20 \mathrm{~m}^{2}, 1$ komedi putar, 1 restok, 1 rumah pasir, $10 \mathrm{kran}$ air tempat wudhu , Terowongan Ban, Brugak taman, Titian jalan setapak 


\begin{tabular}{|c|c|c|c|c|}
\hline $\mathrm{N}_{0}$ & Jenis ruang & Jumlah & Luas & Fasilitas \\
\hline 1 & Ruang belajar & 3 & $200 \mathrm{~m} 2$ & $\begin{array}{l}\text { Peralatan belajar seperti meja, ku } \\
\text { papan tulis, dll. Terdapat } 5 \text { sen } \\
\text { (Balok, Seni, Peran, Persiapan, Bal } \\
\text { Alam) dan kelengkapannya }\end{array}$ \\
\hline 2 & Ruang tidur & 2 & $100 \mathrm{~m} 2$ & $\begin{array}{l}\text { Beberapa baby-box Beberapa tem } \\
\text { tidur anak dan kelengkapannya }\end{array}$ \\
\hline 3 & $\begin{array}{l}\text { Ruang } \\
\text { Administrasi dan } \\
\text { Kepala Sekolah }\end{array}$ & 1 & $20 \mathrm{~m} 2$ & $\begin{array}{l}\text { Mebelair (meja, kursi, lemari, dl } \\
\text { set computer lengkap }\end{array}$ \\
\hline 4 & Ruang dapur & 1 & $20 \mathrm{~m} 2$ & $\begin{array}{l}\text { Kulkas, kompor, dan peralatan da] } \\
\text { lainnya. }\end{array}$ \\
\hline 5 & Ruang ganti & 1 & $25 \mathrm{~m} 2$ & Lemari anak (locker), cermin, karps \\
\hline 6 & Ruang makan & 1 & $60 \mathrm{~m} 2$ & Meja dan kursi makan \\
\hline 7 & Kamar mandi & 3 & $15 \mathrm{~m} 2$ & Peralatan kamar mandi \\
\hline 8 & Teras & 1 & $60 \mathrm{~m} 2$ & Kursi Tunggu \\
\hline 9 & Brugak & 1 & $3 m \times 4 m$ & \\
\hline
\end{tabular}

Pembelajaran: Stimulasi terhadap perkembangan anak dilakukan sepanjang hari ketika anak berada di TPA. Namun pembelajaran yang sifatnya lebih formal dilakukan dari jam 8.00 WITA sampai dengan jam 11.00 WITA. Stimulasi terhadap perkembangan anak dilakukan sesuai dengan kebutuhan dan tingkat perkembangan anak, dan dilakukan untuk semua aspek perkembangan anak (secara holistic). Dalam pelaksanaan proses pembelajaran, anak dikelompokkan berdasarkan kelompok umur. Kelompok anak terdiri dari:

1. Kelompok 0-1 tahun, stimulasi dilakukan secara individual

2. Kelompok 2-3 tahun, stimulasi dilakukan secara individual dan di dalam kelompok

3. Kelompok 3-4 tahun, stimulasi dilakukan secara individual dan di dalam kelompok di dalam sentra permainan atau dalam kegiatan bebas

4. Kelompok 4-5tahun, stimulasi dilakukan secara individual dan di dalam kelompok di dalam sentra permainan atau dalam kegiatan bebas

5. Kelompok 5 tahun ke atas, stimulasi dilakukan secara individual dan di dalam kelompok di dalam sentra permainan atau dalam kegiatan bebas

Peserta Didik: Peserta didik per Januari 2015 untuk TPA berjumlah 32 Anak, Jurnal Ilmiah Mandala Education peserta didik perjanuari 2015 untuk KB berjumlah 39 anak dan TK 32 anak

Ketenagaan: Sumber daya manusia pengelola TPA sehari-hari terdiri dari 18 orang, yang terdiri dari 1 Kepala Sekolah, 10 orang pendidik, 8 orang pengasuh.
Sumber
Keuangan:
Sumber
keuangan operasional $\mathrm{T}$ PA sepenuhnya berasal dari SPP anak. Pengeluaran keuangan secara garis besar digunakan untuk kegiatan- kegiatan di bawah ini:

1. Gaji pendidik dan pengasuh

2. Kebutuhan makan siang (1kali) dan kudapan anak (1kali)

3. Kebutuhan pembelajaran, pembelian bahan habis pakai seperti kertas,krayon, pensil warna, pensil, penghapus, dll

4. Kebutuhan bahan-bahan pembersih, seperti sabun deterjen, sabun cuci tangan, tissue, bahan dan cairan pengepel lantai, dan sebagainya.

5. Kebutuhan alat-alat kebersihan

6. Kebutuhan kegiatan outing class

7. Kebutuhan kunjungan ke obyek pendukung tema

8. Kebutuhan peningkatan mutu pendidik

9. Kegiatan organisasi pendidik

10. Pemeliharaan gedung, alat, dan taman.

11. Pembayaran listrik, telpon, air

12. Kegiatan guru

13. Penambahan sarana pembelajaran

\section{Daya Dukung:}

1. Berada di lingkungan yang strategis dan kondisi lingkungan sangat mendukung, karena berada di tengah-tengah kampus Universitas Mataram. Dengan demikian nuansa kependidikannya sangat kental.

2. Berada di bawah naungan Universitas Mataram, sehingga mendapat fasilitas gedung dan listrik.

3. Untuk mahasiswa melakukan observasi dan melakukan penelitian dalam rangka studi masing masing fakultas yang bersangkutan.

4. Dapat memanfaatkan fasilitas klinik kesehatan Unram dibawah tanggung jawab dokter untuk kebutuhan-kebutuhan mendesak dan pemeriksaan rutin anak.

5. Sebagai tempat magang guru atau mahasiswa PG PAUD dalam rangka menerapkan ilmu yang didapat di 179 
perkuliahan. Dengan berfungsinya sebagai tempat magang bagi mahasiswa, maka secara tidak langsung pendidik dan pengasuh dapat belajar secara tidak langsung dan bertugas untuk PAUD berkaitan dengan pembelajaran.

Berbagai sumber perolehan dana penyelenggaraan PAUD umumnya berasal dari: 1) pemerintah pusat dan pemerintah daerah (provinsi dan kabupaten/kota); 2) masyarakat seperti dari tokoh masyarakat, instansi terkait, dunia usaha dan industri; dan 3) lembaga PAUD sendiri. Kalau kita ilustrasikan dalam bentuk gambar seperti di bawah ini:

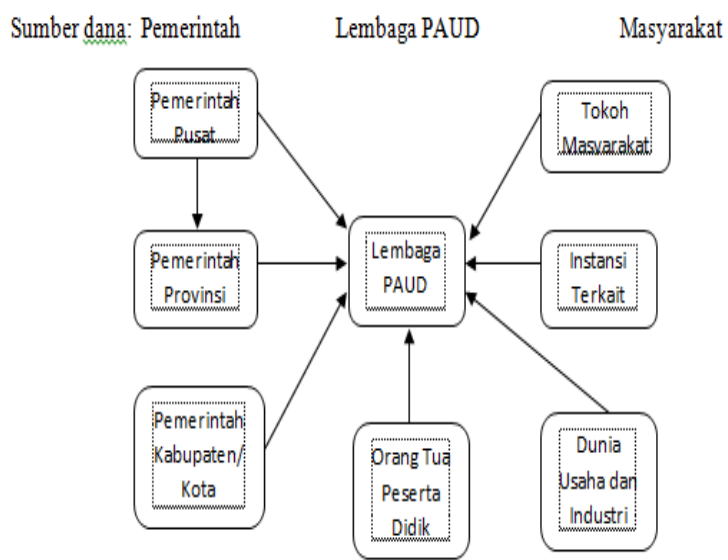

Namun untuk lembaga PAUD yang sifatnya swasta atau swadaya sumber dana penyelenggaraan PAUD yang dikelola oleh lembaga PAUD pada umumnya berasal dari orangtua peserta didik. Karena kalau mengandalkan bantuan dari pemerintah maupun stakeholder yang lain perlu mengajukan proposal atau adanya komunikasi intens dengan pihak-pihak tersebut. Berdasarkan permasalahan-permasalahan tersebut lembaga PAUD harus membuat perencanaan yang matang tentang pengadaan biaya pendidikan di lembaga PAUD. Adapun perencanaan yang dilakukan oleh PAUD Rinjani Unram dalam pengadaan biaya pendidikan melibatkan team pengelolaan PAUD Rinjani Unram, sebagaimana hasil wawancara peneliti dengan Kepala Sekolah sebagai berikut:

............Dalam
merencanakan pengadaan
biaya di PAUD Rinjani Unram

Jurnal Ilmiah Mandala Education ada beberapa langkah yang dilakukan oleh team pengelola PAUD Rinjani Unram dengan rapat pengelola, Pembina PAUD dan kepala sekolah dengan membahas biaya rutin yang digunakan untuk operasional seperti bayar gaji pegawai, guru, transfort, biaya konsumsi makan dan snack anak serta guru, biaya operasional, biaya pemeliharaan gedung, fasilitas dan alat-alat pengajaran, biaya pembelian barang-barang habis pakai, renovasi ringan, ataupun investasi berupa sarana baik didalam ataupun di luar kelas dengan membuat Rencana Anggaran Pendapatan dan Belanja (RAPB) untuk menentukan berapa baiaya peserta didik/iuran SPP yang harus dibayar oleh orang tua peserta didik. (Takasun SP.d. 2 April 2018).

Dalam penelitian ini ditemukan berbagai bentuk bantuan dana PAUD yang diperoleh dari orangtua peserta di dik, yai t u b er upa iuran bulanan, sumbangan sukarela yang dapat berupa uang atau barang (bahan sembako seperti beras, kacang ijo, susu), bantuan tenaga, dan sebagai narasumber. Bagi PAUD Rinjani Unram, iuran orangtua umumnya telah ditentukan melalui komite sekolah. Adapun lembaga KB, TPA, dan Pos PAUD besarnya iuran sudah ditentukan pada saat rapat pengelola PAUD. Umumnya uang iuran dari orangtua digunakan untuk operasional penyelenggaraan PAUD seperti pembelian bahan habis pakai (kertas berwarna, pens il b er wa $\mathrm{r}$ na/ cr yo $n$, lem d an sebagainya), listrik, air, kebersihan, dan insentif pendidik dan tenaga kependidikan. Untuk bantuan tenaga dilakukan di lembaga Pos PAUD dimana para orang $t$ ua membantu sebagai nara sumber diberikan orangtua yang berpendidikan PAUD yang ikut berperan serta dalam penyelenggaraan PAUD dan tujua 180 
nnya aga $r$ anak mempunyai rasa menghargai pekerjaan orangtua sep erti dokter. Di lembaga PAUD Rinjani Unram pengalokasian dana (anggaran) pada kegiatan program dibagi menjadi beberapa persentase yaitu:

.........Pengalokasian dana/anggaran pada kegiatan program kerja di PAUD Rinjani yaitu seperti sumber dana dari SPP peserta didik 50\% dialokasikan untuk biaya gaji pendidik, staf serta transfort kegiatan ataupun rapat pengelola, $25 \%$ ddialokasikan untuk makan dan snack anak, $20 \%$ untuk biaya operasional, sedangkan yang $5 \%$ untuk investasi dan pemeliharaan gedung dan sarpras.(Kepala Sekolah, 5 Maret 2018)

Untuk mekanisme penetapan biaya pendidikan peserta didik melibatkan semua pemangku kepentingan internal antara lain: Pembina PAUD, pengelola, kepala sekolah dan guru sedangkan dalam penyusunan Rencana anggaran Pendapatan dan Belanja Sekolah (RAPBS) disesuaikan dengan pemasukan dan pengeluaran keuangan PAUD. Dalam menyusun RAPBS, prinsip penentuan program yang akan dimasukkan kedalam draf usulan RAPBS dilakukan berdasarkan tingkat urgensinya. Kepala PAUD Rinjani berpendapat bahwa program yang wajib diprioritaskan adalah program yang berkenaan dengan proses pembelajaran. Sebagaimana yang dikutip dalam wawancara dengan kepala sekolah:

RAPBS disusun untuk meningkatkan pebelajaran karena dengan adanya RAPBS dapat dievaluasi program " sekolah bisa terlaksana dengan baik. (kepala Sekolah.....)

Pada prinsipnya guru dan pengasuh pada setiap kelompok diinstruksikan oleh kepala sekolah untuk menyusun daftar ususlan kebutuhan atau program kegiatan, harus sesuai kebutuhan atau program/kegiatan. Hal ini sebagaimana yang dijelaskan oleh kepala sekolah:

. Sebelum menyusun RAPBS, pihak sekolah (termasuk didalamnya guru, pengasuh dan kepala sekolah) menentukan skala prioritas seperti diantaranya program tahunan maupun program semesteran. (Mira. Wali Kelas Jurnal Ilmiah Mandala Education
Kelompok B).

Dunia pendidikan (sekolah) sangat terpengaruh oleh berbagai perubahan, baik dalam aspek politik, sosial budaya, ekonom, teknologi, industri, maupun informasi. Pembaharuan dalam aspek-aspek tersebut menuntut para pengambil keputusan kebijakan pendidikan menyesuaikan diri dengan perubahan tersebut. dengan demikian, dalam penyusunan RAPBS penting untuk diperhatikan berbagai peluang pembiayaan pendidikan. Strategi pembiayaan pendidikan dalam penyusunan RAPBS dimulai dengan mengkaji perubahan-perubahan peraturan perundang-undangan, tuntutan peningkatan mutu pendidikan yang mungkin membuka peluang, dalam hubungan ini pemberian kewenangan kepada kepala sekolah (otonomi) untuk mengelola keuangan sekolah yang menjadi tanggung jawabnya menjadi sangat strategis.

Lingkungan pendidikan dapat digolongkan menjadi lingkungan internal dan lingkungan eksternal. Lingkungan internal sekolah mencakup tenaga kependidikan, sarana dan prasarana, kelengkapan fasilitas, dan biaya yang tersedia di setiap sekolah. Sedangkan lingkungan eksternal sekolah mencakup kondisi sosial ekonomi dan aspirasi masyarakat. Faktor-faktor eksternal pendidikan, seperti keadaan sosial ekonomi orangtua murid, aspirasi keluarga sangat berpengaruh terhadap pencapaian prestasiprestasi siswa.

Dapat dipahami bahwa kepala sekolah PAUD Rinjani memang berorientasi kepada kebutuhan guru, pengasuh dan siswa. Setelah tahap penentuan skala prioritas kebutuhan atau program/kegiatan, selanjutnya kepala sekolah membuat daftar alokasi anggaran secara lengkap mengenai semua kebutuhan atau program/kegiatan. Daftar alokasi tersebut dipresentasikan dalam rapat yang dihadiri oleh kepala sekolah yang juga dihadiri oleh orang tua siswa. Namun dalam pelaksanaannya tidak selalu sesuai harapan karena kesibukan orang tua siswa yang ratarata bekerja sehingga pada saat undangan rapat RAPBS kurang mendapat respon yang maksimal. Sebagaimana uraian dari kepala sekolah sebagai berikut:

Keterlibatan komite sekolah/orang tua 181 
siswa belum terlaksana dengan maksimal karena disetiap kegiatan kehadiran orang tua responnya masih kurang terkendala kesibukan orang tua masiang-masing peserta didik.(Kepala Sekolah......)

$$
\text { Selanjutnya dalam proses }
$$

penganggaran terjadi permasalahan dan kendala yang biasa terjadi dalam setiap tahunnya diantaranya untuk operasional disaat bulan puasa ataupun diawal tahun ajaran baru karena antara pemasukan dana SPP sedikit sesuai dengan jumlah peserta didik yang aktif dan pengeluaran lebih besar terkait untuk biaya pokok gaji guru dan staf yang harus dibayarkan sumber dana biaya operasional dari pesertadidik.

Untuk tahap akhir yaitu evaluasi
dalam rangka penggunaan anggaran. Menurut Kepala sekolah untuk laporan RAPBS dilakukan setiap bulan untuk lembaga dan untuk dana bantuan yang ada seperti BOP satu kali dalam setahun. Sedangkan untuk laporan rutin bulanan disampaikan kepada Ketua Yayasan dan BPPU Universitas Mataram, sedangkan untuk laporan dana BOP kedinasan Pendidikan Kota Mataram.

\section{Kesimpulan dan hasil}

Berdasarkan temuan hasil penelitian dapat dismpulkan bahwa: perencanaan yang dilakukan oleh PAUD Rinjani Unram dalam pengadaan biaya pendidikan melibatkan team pengelolaan PAUD Rinjani Unram. Dalam penelitian ini ditemukan berbagai bentuk bantuan dana PAUD yang diperoleh dari orangtua pe serta didik, yaitu berupa iuran bulanan, sumbangan sukarela yang dapat berupa uang atau barang (bahan sembako seperti beras, kacang ijo, susu), bantuan tenaga, dan sebagai narasumber. Bagi PAUD Rinjani Unram, iuran orangtua umumnya telah ditentukan melalui komite sekolah. Adapun lembaga KB, TPA, dan Pos PAUD besarnya iuran sudah ditentukan pada saat rapat pengelola PAUD. Umumnya uang iuran dari orangtua digunakan untuk operasional penyelenggaraan PAUD seperti pembelian bahan habis pakai (kertas berwarna, pens il b er wa r na/ cr yo $n$, lem d an sebagainya), listrik, air, kebersihan, dan Jurnal Ilmiah Mandala Education insentif pendidik dan tenaga kependidikan. Untuk bantuan tenaga dilakukan di lembaga Pos PAUD dimana para orangt ua membantu sebagai nara sumber diberikan orangtua yang berpendidikan PAUD yang ikut berperan serta dalam penyelenggaraan PAUD dan tujuannya aga $r$ anak mempunyai rasa menghargai pekerjaan orangtua seperti dokter. Untuk mekanisme penetapan biaya pendidikan peserta didik melibatkan semua pemangku kepentingan internal antara lain: Pembina PAUD, pengelola, kepala sekolah dan guru sedangkan dalam penyusunan Rencana anggaran Pendapatan dan Belanja Sekolah (RAPBS) disesuaikan dengan pemasukan dan pengeluaran keuangan PAUD. Dalam menyusun RAPBS, prinsip penentuan program yang akan dimasukkan kedalam draf usulan RAPBS dilakukan berdasarkan tingkat urgensinya. Kepala PAUD Rinjani berpendapat bahwa program yang wajib diprioritaskan adalah program yang berkenaan dengan proses pembelajaran. Pada prinsipnya guru dan pengasuh pada setiap kelompok diinstruksikan oleh kepala sekolah untuk menyususn daftar ususlan kebutuhan atau program kegiatan, harus sesuai kebutuhan atau program/kegiatan. Dapat dipahami bahwa kepala sekolah PAUD Rinjani memang berorientasi kepada kebutuhan guru, pengasuh dan siswa. Setelah tahap penentuan skala prioritas kebutuhan atau program/kegiatan, selanjutnya kepala sekolah membuat daftar alokasi anggaran secara lengkap mengenai semua kebutuhan atau program/kegiatan. Daftar alokasi tersebut dipresentasikan dalam rapat yang dihadiri oleh kepala sekolah yang juga dihadiri oleh orang tua siswa. Namun dalam pelaksanaannya tidak selalu sesuai harapan karena kesibukan orang tua siswa yang ratarata bekerja sehingga pada saat undangan rapat RAPBS kurang mendapat respon yang maksimal. Selanjutnya dalam proses penganggaran terjadi permasalahan dan kendala yang biasa terjadi dalam setiap tahunnya diantaranya untuk operasional disaat bulan puasa ataupun diawal tahun ajaran baru karena antara pemasukan dana SPP sedikit sesuai dengan jumlah peserta didik yang aktif dan pengeluaran lebih besar terkait untuk 
biaya pokok gaji guru dan staf yang harus dibayarkan sumber dana biaya operasional dari pesertadidik.

Untuk tahap akhir yaitu evaluasi dalam rangka pertanggungjawaban penggunaan anggaran. Menurut Kepala sekolah untuk laporan RAPBS dilakukan setiap bulan untuk lembaga dan untuk dana bantuan yang ada seperti BOP satu kali dalam setahun. Sedangkan untuk laporan rutin bulanan disampaikan kepada Ketua Yayasan dan BPPU Universitas Mataram, sedangkan untuk laporan dana BOP kedinasan Pendidikan Kota Mataram.

Dalam penelitian ini ada beberapa saran yaitu:

1. Bagi Kepala Sekolah PAUD Rinjani Unram hendaknya memperhatikan kelengkapan dokumen penyusunan RAPBS, seperti struktur tim penyusun, notulensi rapat penyusunan RAPBS, dan rincian RAPBS yang jelas tentang sumber dana dan alokasi belanjanya.

2. Diharapkan mampu memperhatikan analisis lingkungan internal dan eksternal sekolah, dengan maksud agar penyusunan RAPBS sesuai dengan visi, misi, dan tujuan sekolah.

3. Diperlukan sosialisasi dan koordinasi yang lebih intensif dari Kepala Sekolah kepada semua pemangku kepentingan yang terlibat dalam penyusunan RAPBS. Hal ini dalam rangka mempermudah untuk menyamakan persepsi antarp pihak tentang penyusunan RAPBS.

\section{Daftar Pustaka}

Departemen Pendidikan dan Kebudayaan.1990. Pedoman Guru Bidang Pengembangan Pengetahuan di Taman Kanak-Kanak. Jakarta: Departemen Pendidikan dan Kebudayaan

Departemen Pendidikan dan Kebudayaan. 2003. Undang-Undang Sistem Pendidikan Nasional. Jakarta: Departemen Pendidikan dan Kebudayaan

Tim Dosen Administrasi Pendidikan UPI. 2009. Manajemen Pendidikan. Bandung: Alfabeta

Departemen Pendidikan Nasional. 2008. Undang-Undang Sistem Pendidikan Nasional. Bandung: Citra Umbara

Bogdan, R C dan Biklen S K. 1998. Jurnal Ilmiah Mandala Education
Qualitative Research for Education An Introduction to Theory And Methodes. Boston: Allyn and Bacon, Inc

Bogdan, R C dan Biklen S K. 1982. Qualitative Research for Education An Introduction to Theory And Methodes. Boston: Allyn and Bacon, Inc

Miles, M. B dan Huberman A M. 1992. Analisis Data Kualitatif Buku Sumber Tentang Metode- metode baru. Diterjemahkan Oleh Tjepjep Rohendi Rohidi. Universitas Indonesia

Moleong, L J. 1996. Metode Penelitian Kualitatif. Bandung: PT Remaja Rosdakarya

Nasution. S. 1996. Metode Penelitian Naturalistik-Kualitatif. Bandung: Tarsito

Bandung Bafadal, I. 2005. Dasar-Dasar Manajemen dan Supervisi Taman Kanak Kanak. Jakarta: Bumi Aksara

Rahmayani, I. 2014. Pengelolaan dan Program di Pendidikan Anak Usia Dini. Mataram: FKIP Unram 